\title{
Private Military and Security Companies in UN Peacekeeping Operations: Problems and Perspectives
}

\author{
Maria A. Nebolsina
}

https://doi.org/10.46272/2587-8476-2020-11-3-61-77

\begin{abstract}
While some of the UN member states refrain from providing peacekeepers due to security reasons, the UN frequently turns to the private security market for support. In turn, private military and security companies (PMSCs) take on risky missions and fill in the procurement gaps. It is common practice to criticize PMSCs for not having a clear international legal status, operating in the "grey" area of the law and not being accountable for their actions. Furthermore, the UN often equates PMSCs to mercenaries of the past and calls for strict regulation and surveillance of their activities. This practice has remained unchanged since the 1992 reforms, and the UN has done nothing to reduce the involvement of PMSCs in peacekeeping missions. On the contrary, it has, under pressure from lobbyists for the private security industry, actually increased security expenditures for PMSCs by unprecedented amounts. The UN's position as a unique universal intergovernmental organization exempts it from a great deal of transparency, accountability and reform. While the private security industry includes various PMSCs that compete for contracts

in conflict zones and post-conflict areas, the UN does not have any kind of competitor in peacekeeping procedures. The UN criticizes PMSCs for their blatant human rights violations and disregard of international law, yet continues to contract them for its peacekeeping missions. This paper examines the problem of involving PMSCs in UN peacekeeping operations. It aims to answer the following main questions: How do PMSCs, as partners of the UN in the peacekeeping process, contribute to the protection of human rights, which is one of the organization's basic declared principles? Can PMSCs become a recognized instrument within the UN system? Would UN peacekeeping efforts improve as a result of hiring PMSCs?
\end{abstract}

\section{KEYWORDS}

PMSCS, the UN, peacekeeping operations, efficiency and effectiveness of missions, outsourcing and privatization of security, mercenarism, accountability of PMSCs 
The tendency to outsource state military and security functions to PMSCs does not only apply to conflict- and war-torn regions, but also takes place during peacekeeping missions and humanitarian operations. Both individual countries and international organizations started to contract PMSCs to take part in their post-conflict missions, an example of which is the United Nations' use of PMSCs in many of its missions in Africa. Moreover, almost all UN operations that involve demining today are carried out by PMSCs. The extent of PMSCs' engagement in UN activities, as well as their efficiency, effectiveness and indispensability are still to be evaluated.

Different aspects of research on peacekeeping ${ }^{1}$ and the UN system in general, ${ }^{2}$ as well as the use of public-private and PMSC partnerships in peacekeeping operations have been dealt with in detail by a number of authors. While some believe that PMSCS have the potential to be used in peacekeeping missions and that their involvement can be useful, ${ }^{3}$ others question their engagement in the peace process for various reasons ${ }^{4}$ and question the ability of PMSCs to keep the peace. ${ }^{5}$ Some researchers believe in cooperation between the UN and PMSCs. ${ }^{6}$ Others study the accountability of PMSCs, as well as the financial, economic, military, political and legal aspects of outsourcing military activities. ${ }^{7}$ The matter was also raised by the UN Working Group (WG) on the Use of Mercenaries as a Means of Violating Human Rights and Impeding the Exercise of the Right of Peoples to Self-Determination.

The UN has certain experience delegating functions to NATO, the EU, OSCE, CIS and OAU. ${ }^{8}$ While PMSCs are non-state actors, some experts suggest delegating a number of tasks to them under the effective supervision of the Secretary General. ${ }^{9}$ After two unsuccessful UN peacekeeping missions in Somalia (1993) and Rwanda (1994), former Secretary-General Boutros Boutros-Ghali stated that: "in certain operations we will not be successful," but it "must not be an obstacle to additional operations all over the world."10 Since that time, a number. Since that time, a number of PMSCs have been contracted to support the UN's peace activities in various missions. ${ }^{11}$

What role do PMSC contractors play in UN missions? Who is responsible for the outsourced peace activities? Can PMSCs be effective in security matters during peacekeeping operations? If so, what measures does the UN take to ensure the world that PMSCs are effective and indispensable from a procedural point of view? Can the involvement of PMSCs itself be measured and what are the criteria by which one should judge the success or failure of outsourcing peacekeeping functions? There is an ethical component to these issues that should not be ignored either. Are PMSCs, as business-oriented entities, more concerned about cost-cutting than they are about peace (or other) operations, security issues and respect for human rights? Are PMSCS

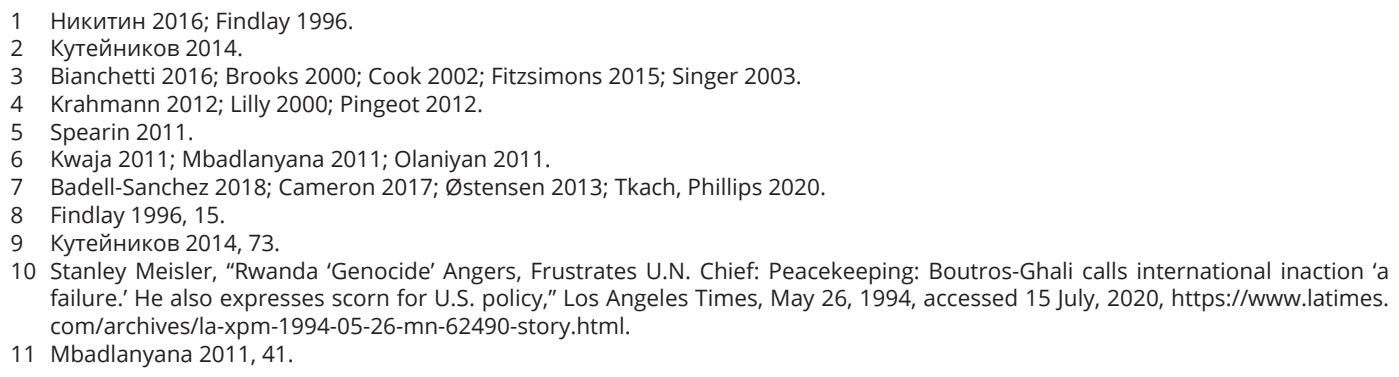

10 Stanley Meisler, "Rwanda 'Genocide' Angers, Frustrates U.N. Chief: Peacekeeping: Boutros-Ghali calls international inaction 'a failure.' He also expresses scorn for U.S. policy," Los Angeles Times, May 26, 1994, accessed 15 July, 2020 , https://www.latimes. com/archives/la-xpm-1994-05-26-mn-62490-story.html.

11 Mbadlanyana 2011, 41. 
more willing to uphold the peace or uphold the terms of their contracts? Finally, are PMSCs a new peacekeeping instrument in the UN arsenal? Or are they supposed to substitute general and well-known UN peacekeeping mechanisms by becoming a shadow force with which the UN can terminate relations whenever necessary?

One more thing, it should be noted that the words "peacekeeping operations" are used as an umbrella term, as it encompasses a number of different forms of international involvement in conflicts. This allows us to consider a wide range of measures currently employed by the UN - from intermediary and preventative activities to peace enforcement with the use of military and police forces. Aside from traditional peacekeeping, today we are seeing a new hybrid type of operations (the African Union-United Nations Hybrid Operation in Darfur) and political missions (in Afghanistan, Iraq, Libya, etc.). Currently, the UN is conducting 14 peacekeeping operations under the guidance of the UN Department of Peacekeeping Operations and 25 political missions and good office engagements under the guidance of the United Nations Department of Political and Peacebuilding Affairs. ${ }^{1}$ Together, these missions involve approximately 120,000 military, police and civil personnel, with a ratio of 5:1 meaning five military and police force personnel to just one diplomat and/or other civil specialist. $^{2}$

Secondly, the term "PMSCs" requires some clarification. There is a number of definitions of what PSCs, PMCs and PMSCs are. Experts, scholars and politicians alike have offered their thoughts on the subject. Depending on the battlefield, the recognized "guru" in private military and security analysis P. Singer divides PMSCs into "military provider firms" (implementation and command services), "military consulting firms" (advisory and training services) and "military support firms" (non-lethal aid and assistance). ${ }^{3}$ In his report to Congress, M. Schwartz studies PSCS and classifies their services into two major categories: armed services and unarmed services. ${ }^{4}$ Former head of Sandline International T. Spicer describes PMSCs as "corporate bodies specializing in the provision of military skills to legitimate governments: training, planning, intelligence, risk assessment, operational support and technical skills." ${ }^{5}$ Most scholars agree that PMSCs are not the same thing as mercenaries, ${ }^{6}$ although many do liken them to illegal entities and mercenaries. ${ }^{7}$

Given the fact that PMSCs are a multifaceted phenomenon, and the problem of distinguishing between PMSs and PSCs is troublesome, it would be best to operate with the definition given by the Montreux Document - the only international document on the topic - which states that "Private military and security companies (PMSCS) are private business entities that provide military and/or security services, irrespective of how they describe themselves. Military and security services include, in particular, armed guarding and protection of persons and objects, such as convoys, buildings and other places; maintenance and operation of weapons systems; prisoner detention; and advice

\footnotetext{
"UN Peacekeeping operations, Special Political Missions and Other Political Presences," UN, accessed December 13, 2020, https:// www.unmissions.org/.

Никитин 2016, 16.

Singer 2003, 92-100

Schwartz 2011, 2.

Spicer 1999, 15.

Cockayne et al. 2009; Ettinger 2014; Gumedze 2008; Krahmann 2012; Percy 2007a; 2007b.

Coady 1992; Fallah 2006; Lumina 2008; Shearer 1998.
} 
to or training of local forces and security personnel". ${ }^{1}$ The document unites PMCs and PCSS and, unlike the UN draft Convention on PMSCs ${ }^{2}$ (which also gives a definition of PMSCS), it does not separate private security services from private military services.

There is no consent on the use of PMSCs around the world, with legislation regulating the activities of PMSCs differing from country to country. Even such strong normative regulations that were adopted in the US or UK do not guarantee compliance with and observance of human rights by PMSCs. In some states, the local police oversee the activities of PMSCs (for example, in Denmark, Hungary and Slovakia), in others, ministries of the interior perform these functions (for example, Slovenia, Poland and Italy). In Luxembourg, the Ministry of Justice acts as the supervisory body over PMSCs, etc. When hired by state bodies, businesses, NGOs or international organizations, such companies receive some level of legitimacy.

It should be noted that the UN itself engages PMSCs for security services only. When it comes to UN peacekeeping missions under partnership programs, countries are not limited to this rule and can engage PMSCs at their sole discretion. An example of a partnership program is the US Global peacekeeping operations initiative (GPOI) adopted in 2004. As part of this initiative, member states can contract PMSCs to train and instruct local forces for different UN peacekeeping missions. When PMSCS are hired by member states, they, not the UN, are responsible for outsourcing and subcontracting.

In its theoretical part this paper studies the involvement of PMSCs in peacekeeping operations through the several concepts. The end of the Cold War marked the emergence of many local conflicts. This increased the demand for PMSC services to restore stability and order at the local level using a small number of aircraft and technical equipment. Although the priority areas for liberalism are cooperation and collective security, these phenomena cannot be considered in isolation from conflicts and peacekeeping. PMSCs actively began to enter the markets of those states where their assistance was required, and where the international community did not show any special interest, seeing such armed clashes as internal processes. In cases where foreign forces did interfere in conflicts, international organizations themselves began to get PMSCs involved in peacekeeping and humanitarian operations. ${ }^{3}$ According to the UN Working Group on the Use of Mercenaries as a Means of Violating Human Rights and Impeding the Exercise of the Right of Peoples to Self-Determination, as of May 2014, approximately 30 private military and security companies were involved in the organization's missions.

The concept of network or hub management in the security field explores the process of the emergence of fragmented but overlapping networks that form the basis for cooperation between state and non-state actors. The decentralized "nature of the network makes it possible for nodes to leave the network and connect to it at any time [...] The significance of nodes does not stem from their specific features, but from

1 "The Montreux Document on Pertinent International Legal Obligations and Good Practices for States Related to Operations of Private Military and Security Companies During Armed Conflict," International Committee of the Red Cross, 2009, accessed December 15, 2020, https://www.icrc.org/en/publication/0996-montreux-document-private-military-and-security-companies.

2 "UN Draft International Convention on the Regulation, Oversight and Monitoring of Private Military and Security Companies," MGIMI University, July 13, 2009, accessed December 15, 2020, https://mgimo.ru/files/121626/draft.pdf.

3 Gumedze 2011. 
their ability to distribute information. In this sense, the main nodes are the switching nodes. Each node (actor) in the system has network power, which is the ability to influence the activities of other participants. However, this influence cannot be imposed, that is, the network power is different from the authority of the command."1 This network behavior can be seen in the example of peacekeeping missions. When a peacekeeping operation begins, the PMSCs that are involved in it become the nodal link in the network that was formed when the mission began. However, as the mission is completed and moved from one region to another, PMSCs, as a network link, follow the new mission. At the same time, they cease to play an important role, leaving the network when the mission is finished in a given place, and then form other nodes and thus enter other networks in new peacekeeping missions.

Speaking about changes in the nature of conflicts and wars that can be explained by the concept of a new type of war, the author dares to offer the concept of a new type of peacekeeping. If traditional wars are superseded by non-classical and nonstate conflicts that are related to modern challenges and threats, then traditional peacekeeping operations undergo a process of adjusting to the new conflict resolution reality. Thus, the privatization of the security sphere and the formation of global security networks occur simultaneously with other global processes, in particular, with the change in nature of contemporary peacekeeping and the transformation of approaches to the use of peacekeeping instruments in modern society. Similar to modern conflicts, be they "asymmetric," "hybrid," "informal," "low-intensity," etc., peacekeeping seeks non-traditional ways to settle conflicts using the new tools that are available to them. And PMSCs are among these tools.

\section{Pros and Cons of the Historical Involvement of PMSCs in UN Peacekeeping Missions}

The pace and scope of the UN peace activities have changed since the end of Cold War. The rise in peace activities has come as a consequence of the fact that the global superpowers lost interest in their smaller client states. Numerous armed conflicts that had previously been contained through the proxy involvement of superpowers, as well as new conflicts that emerged with the collapse of the old system, revealed the need for negotiated settlements all over the world. The number of countries that provided the UN with peacekeepers almost trebled in the period from 1988 to 1994, from 26 to $76 .^{2}$ Thus, the UN had to deploy almost 80,000 troops in 18 missions in 1993, compared to fewer than 10,000 peacekeepers in just five operations in $1988 .^{3}$ The scope of peacekeeping functions has also transformed. In addition to traditional peacekeeping functions, peace enforcement efforts were also needed. There was a remarkable increase in the number of new missions, which created more tasks: observing elections, providing assistance to and repatriating refugees, protecting human rights, training, demining, providing humanitarian assistance, disarming military and paramilitary groups, etc. The difficult environment and the complexity 
of multitasking, together with the failures in Somalia and Rwanda, led to a situation where many western countries were discouraged from sending ground troops, at least to participate in African peacekeeping missions.

This situation forced the US to launch an initiative that would prevent the country from joining peacekeeping operations "unless the conflict threatens international peace and security or served US interests." 1 The very idea of the initiative appeared due to the reluctance of the US to participate in peacekeeping operations following the failure of the Somalia peacekeeping missions in the 1990s. This led to the rise in demand for PMSCs to form a part of the tools available to UN peacekeeping missions. Moreover, a number of experts believe that engaging PMSCs is a sign of success and that peacekeeping operations can be made more innovative with "tactical military assistance," something that PMSCs successfully provide. ${ }^{2}$

Twenty years ago, when the process that K. Annan labelled the "privatization of peace" began, ${ }^{3}$ concerns were raised about the unclear and dangerous implications of privatization in terms of peace and security. ${ }^{4}$ Since then, the role of PMSCs in peacekeeping operations remains a point of contention. While some experts believe that "PMSCs can play an essential role in peacekeeping missions and contribute to the organization of the mission," ${ }^{5}$ and that the industry of private security demonstrates its "ability to quickly mobilize a small unit of contractors and execute a precise mandate in a very effective manner, ${ }^{16}$ others argue that this shifts "authority over peacekeeping from the UN onto the more diffuse structure of the commercial market [...] with a very low degree of transparency," ${ }^{7}$ and reduced "the UN's day-to-day control over security; and, thus, the organization surrenders some control over peacekeeping's beneficiaries and development priorities."8

The concerns about the use of PMSCs were confirmed in 1992 when the UN hired several contactors for a four-year peacekeeping operation in Bosnia. "Soon after deployment, a serious scandal erupted in the Bosnia mission. DynCorp personnel, working as police officers under US contract but UN command, were found to be involved in sex trafficking and organized prostitution." ${ }^{\prime 9}$ Still, the UN requires helicopters, armored vehicles and military equipment, as well as maintenance, air and airlift services in mission zones.

A report of the UN Working Group on the Use of Mercenaries as a Means of Violating Human Rights and Impeding the Exercise of the Right of Peoples to SelfDetermination states that the UN used armed PMSCs in three countries and engaged PMSCs for unarmed services in 23 countries where political and peacekeeping missions continue. According to the Report, the total budget for the use of PMSCs in 20132014 was estimated at approximately $\$ 42 \mathrm{mln}$, including $\$ 14 \mathrm{mln}$ for armed services

2 Brooks 2000, 6; Singer 2003, 118; Bianchetti 2016, 48.

3 “Secretary-General Reflects on 'Intervention' in Thirty-fifth Annual Ditchley Foundation lecture," UN Press Release SG/SM/6613, June 26, 1998, accessed November 30, 2020, https://www.un.org/press/en/1998/19980626.sgsm6613.html.

4 Lilly 2000, 5.

Badell-Sánchez 2018, 12

Bianchetti 2016, 48.

Østensen 2013, 44.

Tkach, Phillips 2020, 106.

Pingeot 2012, 22. 
(the peacekeeping mission in Haiti and political mission in Afghanistan were estimated at $\$ 5.12 \mathrm{mln}$ and $\$ 8.89 \mathrm{mln}$, respectively). ${ }^{1}$

UN cooperation with PMSCs generally covers three main areas: logistical and transport support(bases, airports, etc.); security and policing (demining, disarmament, security for UN personnel and premises, etc.); and frontline forces support (training and instructing peacekeepers). These functions were traditionally carried out by UN Peacekeeping personnel, but are now outsourced to third parties due to the current lack of UN specialists. ${ }^{2}$ For example, the PMSC International Charter Incorporated (ICI) was used by the UN "to ferry personnel, troops and supplies into and within Liberia, Sierra Leone and Nigeria" for the purposes of peacekeeping operations. Another PMSC, Defence Systems Limited provided intelligence and logistical "support for national contingencies participating in the UN-sanctioned International Force in East Timor[...], while DynCorp has supplied helicopter transport and satellite network communications." The UN and PMSCs also cooperated in Angola, where the UN turned to a private company "to provide intelligence on UNITA's guns-forgems trade." "During the crisis in Liberia, MPRI trained the Nigerian peacekeeping forces in the ECOMOG contingent in the effective handling of military vehicles supplied by the US government."

It should be noted that such tasks as logistics and transport support, security and policing, and even training and instructing peacekeepers are general activities that contractors can successfully manage if the context is other than that of a peacekeeping operation, post-conflict settlement, armed conflict or any sensitive context of the kind. If the same tasks are placed in the abovementioned sensitive context and outsourced to PMSCs, they are immediately accompanied by the responsibility of guaranteeing that human rights will be fully observed. The problem with the use of private military contractors is that "unlike state forces, [they] operate outside criminal law regimes, without adequate oversight."

Now, PMSCs are contracted for all UN missions that involve demining. For example, G4S actively assists the UN in demining activities. Previously, South African PMSC Denel largely cooperated with the UN in Somalia and Mozambique, providing mineprotected vehicles and other equipment. It is reported that UNICEF, WFP, UNHCR, UNDP and the UN Procurement Division are amongst the largest UN agencies and bodies contracting PMSCs. ${ }^{6}$

It is not only the UN and its bodies that directly outsource security functions, as the member states deployed within UN missions do as well. Yet, there is no UN document in place that covers all aspects of cooperation with PMSCs in peacekeeping missions, including partnership programs, "against which to measure the possibility to use PMSCs as a troop contingent."

1 "Report of the Working Group on the Use of Mercenaries as a Means of Violating Human Rights and Impeding the Exercise of the Right of Peoples to Self-determination," UN doc. A/69/338, August 21, 2014, accessed December 15, 2020, https://undocs. org/A/69/338.

2 Badell-Sánchez 2018, 11.

3 Olaniyan 2011, 9.

George 2011, 26.

Fitzsimons 2015.

Bianchetti 2016, 8.

Cameron 2017, 54. 
On 30 March 2018, the 15-year long UN peacekeeping mission in Liberia came to an end. The Liberian forces had completed training with DynCorp and Pacific Architects \& Engineers (PAE) - both PMSCs hired by the US under the initiative. Another giant in the PMSC sector, G4S, is engaged in "minefield mapping and battlefieldordnance disposal" under the auspices of the UN peacekeeping mission in South Sudan. ${ }^{1}$ After several years working under a UN contract as part of the partnership program "the combined efforts of G4S and other demining groups [...] have cleared merely 835 square miles of suspect land, with large tracts remaining to be done." ${ }^{2} \mathrm{It}$ operates there alone. But "the UN's limited command and control over PMSCs can incur unaccounted for legitimacy costs."

A number of experts challenge the argument that PMSCs are effective because, on the whole, they question the ability of PMSCs to successfully carry out peacekeeping tasks, and the results of outsourcing peacekeeping are impossible to measure. ${ }^{4}$ Even if it were possible to state that the use of PMSCs in UN missions is unambiguously justified and demonstrates success, efficiency alone can clash with accountability and discredit the UN principles of maintaining peace and security, and its adherence to human rights.

Some experts attribute the greater role of PMSCs in UN peacekeeping missions to the procedural imperfection of the United Nations itself. The lack of UN peacekeeping personnel can be traced back to the results of 1992 reforms, rather than to technical problems or the shortage of resources. "The mandate process [...] remains largely unchanged" since the 1992 reforms, though the UN doctrinal concept of peacekeeping operations has changed dramatically over the past 20 years. ${ }^{5}$ Two UN documents dating back to 2000 and 2001, respectively, justify international intervention in conflicts: the 2000 Report of the Panel on UN Peacekeeping operations (Brahimi Report) on Humanitarian Intervention ${ }^{6}$ and the 2001 Responsibility to Protect report published by the International Commission on Intervention and State Sovereignty (ICISS) that was set up by the Canadian government. ${ }^{7}$ This became possible in part because of the imperfectly reformed procedures that let the UN member states preserve "extensive influence on mandates, troop contributions, and procurement" and eventually resulted in the broader involvement of PMSCS in peacekeeping missions. ${ }^{8}$

A Transparency International report on Corruption Risks on UN Peacekeeping Operations states that lobbying does exist, "particularly relating to procurement," though there is "no register of lobbying activity that is kept or published." ${ }^{9}$ While there is clear evidence that PMSCs are engaged in peacekeeping missions,

1 William Langewiesche, “The Chaos Company," Vanity Fair, April 2014, accessed July 15, 2020, https://www.vanityfair.com/news/ business/2014/04/g4s-global-security-company.

2 Ibid.

3 Tkach, Phillips 2020, 114.

4 Ibid., 106-107.

5 Ibid., 106.

6 "Report of the Panel on United Nations Peace Operations (Brahimi Report)," UN doc. A/55/305-S/2000/809, August 21, 2000, accessed November 30, 2020, https://www.un.org/peacebuilding/content/report-panel-un-peace-operations-brahimi-report.

7 "Responsibility to Protect - A Short History," UNRIC, accessed December 15, 2020, https://archive.unric.org/en/responsibility-toprotect/26981-r2p-a-short-history.

8 Tkach, Phillips 2020, 106.

9 "An Assessment of Corruption Risks in UN Peace Operations," Transparency International, May 2019, accessed December 13, 2020, https://ti-defence.org/wp-content/uploads/2019/07/TIDS-CorruptionRisksinUNPeacekeeping.pdf. 
the UN remains hesitant to disclose information about these facts. ${ }^{1}$ The vague accounting within the UN system does not state the degree of involvement of PMSCs in peacekeeping operations. The most famous PMSCs lobbying group the International Stability Operations Association (ISOA) - tries to present a positive image of private military and security contractors and position them as the "new humanitarians" who can become a good alternative to the UN peacekeepers. ${ }^{2}$ At the same time, the "security industry has placed key personalities within [...] relevant institutions to secure its interests." ${ }^{\text {I I }}$ is known that the UN "Department of Safety and Security (DSS) plays a key role in promoting PMSCs and advocating for a 'hard' security perspective."

Former Assistant Secretary of State for Diplomatic Security G. Starr is a vivid example of an ardent advocate for outsourcing within the UN. Appointed by UN Secretary-General B. Ki-moon, G. Starr held the position of the UN Under-SecretaryGeneral for Safety and Security from May 2009 to January 2013. He was in charge of overseeing the "formulation of security policies and the implementation of programs to ensure the conduct of activities in a secure environment at U.N. headquarters and overseas locations around the globe." ${ }^{5} \mathrm{UN}$ expenditures on PMSCs increased dramatically during Starr's tenure. UN security services costs accounted for approximately USD $\$ 12.8 \mathrm{mln}$ in 2009 before skyrocketing to USD $\$ 75.7 \mathrm{mln}$ in 2010, USD \$113.8 mln in 2011 and USD \$124.3 mln in 2012. ${ }^{6}$ Though it was not quite clear what the security services implied, the figures proved "a rapid increase in the use of security service firms." ${ }^{17}$ A similar expansive outsourcing of security to PMSCs could be observed during G. Starr's time as head of the State Department's Diplomatic Security Service. ${ }^{8}$

\section{Problems with Separating PMSCs from Mercenaries and Related Matters}

While those who oppose outsourcing security challenge the effectiveness and efficiency of PMSC, those who are in favor criticize these institutions for the ineffectiveness and inefficiency. The disturbing aspects of the involvement of PMSCs in peacekeeping operations, which add to the confusion about the private security industry as a whole, are a stumbling block towards the full legitimization and acceptance of PMSCs. Human rights violations, malfeasance, shadow activities, non-transparent contracts, the lack of international legitimacy and accountability, and the fact that "both the industry and the clientele are committed to guarding the secrets of particular missions" are just a few areas of concern. ${ }^{9}$ All of this creates

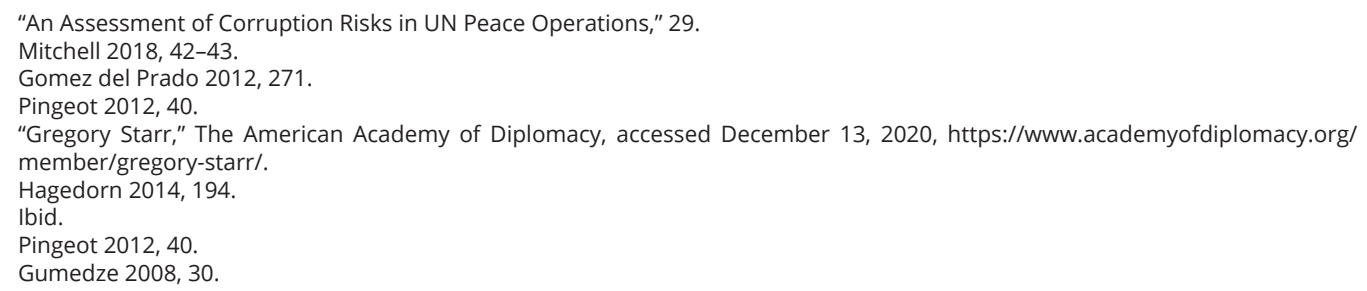


a situation where a number of UN officials" and scholars ${ }^{2}$ see PMSCs as "soldiers of fortune" and equate them to modern mercenaries, which becomes clear when reading the UN Resolutions and different statements by its officials. ${ }^{3}$

On the one hand, the private security industry has a reputation for being mercenaries thanks to a number of notorious episodes. The Blackwater case, the Sandline International Affair, the alleged involvement of Executive Outcomes in African conflicts, and the earlier cases of Watchguard International and Keenie Meenie Services, which became a byword for mercenary private contractors. T. Cook believes that modern PMSCs are a different breed of mercenary that do not hide their activities, defend their "professionalism, training and organization" and have much "more in common with a Wall Street banker than 'Mad Mike."'4 When the UN General Assembly adopted the International Convention against the Recruitment, Use, Financing and Training of Mercenaries in 1989 (which came into force in 2001), discussions turned almost immediately to a new phenomenon that of PMSCs - which led to the creation of a mechanism for "treating mercenaries and private military firms as interchangeable actors." ${ }^{15}$ Since then, the stigma of PMSCs as new mercenaries has been successfully reflected in a large number of UN documents. ${ }^{6}$

Moreover, G. Starr was the one who "re-hired Blackwater after the Nisour Square massacre of September 2007 [...] to support the US Government's foreign policy objectives." In this context, it seems that a well-known lobbyist for the private security industry did a disservice to PMSCs.

On the other hand, the UN Working Group on the Use of Mercenaries as a Means of Violating Human Rights and Impeding the Exercise of the Right of Peoples to SelfDetermination, which has been working on the PMSCs convention since 2005, adds to the misunderstanding. ${ }^{8}$ The Working Group has a broad mandate that includes both PMSCs and mercenarism, which also serves to perpetuate the unclear perception of the phenomenon. ${ }^{9}$ While it would be unfair to judge the entire private security industry on the gross violations of human rights committed by the PMSCS mentioned above, the stigmatized image of PMSCs as mercenaries influences society's attitude to the involvement of these companies in UN peacekeeping operations. So, PMSCs could acquire more legitimacy when the UN disassociates them from mercenaries, especially bearing in mind the imperfect definition

1 Bernales 2003; Shearer 1998.

2 Rosemann 2008; Cockayne et al. 2009; Krahmann 2012; Percy 2007a; 2007b; Ettinger 2014.

3 "Mercenaries, Private Military Contractors Can Destabilize Rule of Law, Expert Tells Third Committee, amid Calls to End Racism, Respect Migrant Rights," UN GA/SHC/4246, October 30, 2018, accessed November 30, 2020, http://surl.li/ifdw; Bernales 2003; "United Nations Human Rights Council Resolution E/CN.4/RES/2005/2," UNIDOCS, accessed November 30, 2020, http://surl.li/ifdx; "United Nations Human Rights Council Resolution A/HRC/RES/15/12," UNIDOCS, accessed November 30, 2020, http://surl.li/ifdz; "United Nations Human Rights Council Resolution A/HRC/RES/24/13," UNIDOCS, accessed November 30, 2020, http://surl.li/ifea; "United Nations Human Rights Council Resolution A/HRC/RES/24/13," UNIDOCS, accessed November 30, 2020, http://surl.li/ifea; "United Nations Human Rights Council Resolution. A/HRC/RES/33/4," UNIDOCS, accessed November 30, 2020, http://surl.li/ifdt.

4 Cook 2002.

5 Ettinger 2014, 174

6 "United Nations General Assembly Resolution A/RES/54/151," UNIDOCS, accessed November 30, 2020, http://surl.li/iojr; "UN Human Rights Commission Fact Sheet no. 28," World Campaign for Human Rights, 2002, accessed December 16, 2020, https:// www.ohchr.org/Documents/Publications/FactSheet28en.pdf.

7 Pingeot 2012, 40.

8 "Remarks by Gabor Rona," UN Working Group on the Use of Mercenaries, Montreux +5 Conference," December 11-13, 2013, accessed November 30, 2020, http://surl.li/ifeb.

9 "The Use of Private Military and Security Companies in UN Peace and Humanitarian Operations in the Field," UN Press Conference, August 1, 2013, accessed November 25, 2020, http://surl.li/ifee. 
of mercenaries that is replicated in a number of international documents. ${ }^{1}$ Yet, it remains clear that a decision on the rehabilitation of Blackwater impedes the restoration of the image of PMSCs in general.

\section{Possible Solutions}

In 2003, P. Singer - a proponent of use of PMSCs - offered several solutions to some of the issues regarding the UN outsourcing its peacekeeping functions to PMSCs. One of them was to create a private "Rapid Reaction Force" (PRRF) similar to the Intervention Brigade that was once deployed as part of the UN peacekeeping mission in the Democratic Republic of the Congo. The Brigade was deployed for several months; its mandate was to disarm and neutralize rebels in order to stop further violence. The Brigade succeeded in supporting local government forces and defeating violent rebel groups. It was after its involvement that it became possible for the UN to start the political process. Similar to the Intervention Brigade, the PRRF could operate as an immediate remedy for the conflict before the political process starts and the consent of the parties achieved. Operating under a Security Council resolution, the PRRF would acquire legal grounds for their involvement in conflicts. Thus, the UN would bear final responsibility for the PRRF's activity. Additionally, Ch. Spearin argues that "the UN might also demand specific training and interaction amongst PMSC personnel, regardless of nationality or past public sector experience, to ensure operational coherence." ${ }^{2}$

Yet, there are a number of questions to be addressed regarding the legal status of the PRRF under international humanitarian law $(\mathrm{IHL})$, because "politically, of course, the UN would [...] have to persuade member states of the legitimacy

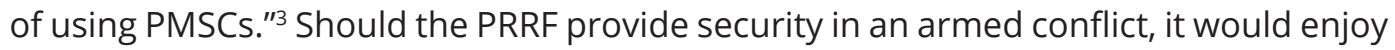
the status granted to members of militias or volunteer corps under the command and authority of the UN. This status is regulated by Additional Protocol 1 (Article 43(2)) and Article 4 (A) of the third Geneva Convention. "In the event of a non-international armed conflict the PRRF would be subject to the provisions of international humanitarian law applying to Non-International Armed Conflict (NIAC) and the provisions of customary international law, including the requirement to distinguish between civilians and combatants when targeting attacks."4

With the UN assuming responsibility for the PRRF, it would also be liable for the vetting process, as well as monitoring, accountability, grievance mechanisms, etc. That is, it would retain overall control. Keeping in mind the fact that the UN member states are reluctant to put their forces at risk, the development of the PRRF under UN command seems to be a new step forward in the evolution of the PMSC industry.

The issue of funding the PRRF is also extremely important. Who will finance it? As far as the member states are responsible for funding UN peacekeeping operations,

1 "Protocol Additional to the Geneva Conventions of 12 August 1949, and Relating to the Protection of Victims of International Armed Conflicts (Protocol I), Article 47, June 8, 1977," 1125 UNTS, 1979, accessed December 13, 2020, http://surl.li/ifef; "OAU Convention for the Elimination of Mercenarism in Africa. July 3, 1977. CM/817 (XXIX). Annex II Rev. 1," OAU, accessed December 13, 2020, http://surl.li/ifeg; "International Convention against the Recruitment, Use, Financing and Training of Mercenaries, December 4, 1989," UNTS 2163, accessed December 13, 2020, http://surl.li/ifeh.

2 Spearin 2011, 205.

3 Ibid., 205-206.

4 Bianchetti 2016, 54. 
it would be logical to create a certain expenditure item within the peacekeeping budget. Thus, the overall cost of peacekeeping missions could be reduced after expenditures are redistributed. The calculation is not difficult, and a number of authors have provided us with figures. The costs of the Executive Outcomes operation in Sierra Leone added up to almost USD $\$ 1.2 \mathrm{mln}$ per month, whereas the UN costs were USD $\$ 19.4 \mathrm{mln}$. The costs per person employed for Executive Outcomes' were USD $\$ 71,429$, compared to USD $\$ 108,756$ for the UN." “'While [Executive Outcomes'] presence in Sierra Leone lasted twenty-one months and cost the government an estimate of USD \$35 mln, the UN peace force totaled more than US $\$ 2.8$ billion costs for a 7 years operation." ${ }^{2}$ In Congo, "the costs have skyrocketed in the last years, from approximately US \$520,000 in 2006 to more than USD $\$ 6 \mathrm{mln}$ in 2011, while total costs for field missions' use of security services around the globe grew from USD $\$ 3.7 \mathrm{mln}$ in 2006 to an astonishing USD \$26.4 mln in 2011."3

\section{Conclusions}

Returning to the ethical question of the involvement of PMSCs in peacekeeping operations and their broader interest in business affairs rather than human rights and security, one must admit that the dilemma lies in the fact that contractors do not belong to the UN system and do not share its values. This is not about PMSCS committing gross violations of human rights, as UN peacekeepers also commit violations themselves. Rather, it is about respect for human rights not being the main priority, as the contractors have admitted. Given the flawed procedures within the UN that have created budget and personnel shortages for peacekeeping missions, the UN has to resort to PMSCs, otherwise it would be at risk of violating the human rights of those it promised to protect. While there is evidence to show that in the short term PMSCs can help restore stability, their main priority is to maximize profit, which raises serious concerns about the expediency of using them in the long term. ${ }^{4}$

As for how PMSCs involved in peacekeeping operations contribute to the protection of human rights, one argument is that they allow UN peacekeeping missions to continue. This premise suggests that the concept of UN peacekeeping operations has transformed, shifting from the main idea of peace settlement and conflict resolution to maintaining peacekeeping operations, which include more robust mandates today. This shift is reflected in the UN's approach to its security management policy, which has evolved from "when to leave" to "how to stay." Following this assumption, we can assert that the UN stands more for maintaining its peacekeeping missions rather than for peace itself.

PMSCs are often accused of being interested in conflicts and wars continuing, given that their contracts are related to military- and security-oriented tasks. When it comes to their participation in UN missions, there is a greater resonance. It seems that, unlike PMSCS, which are interested in keeping their contracts, UN peacekeepers aim

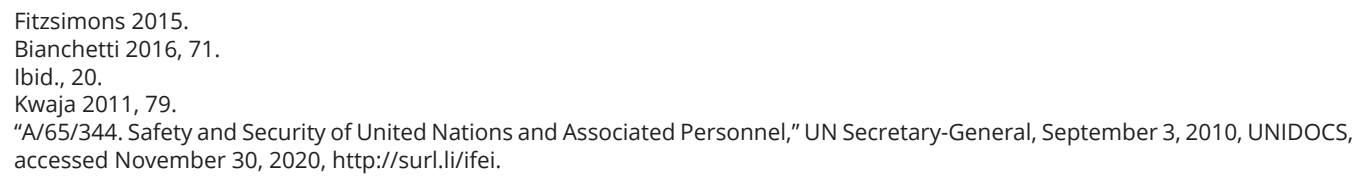


to establish peace and ensure provide stabilization and security. Yet, there are regions with lasting peacekeeping operations, where competing groups do not necessarily strive for peace. Achieving a consensus and welcoming a UN peacekeeping mission can serve as a timeout for fighting groups that sign peace accords but refuse to follow them and eventually breach the negotiated plans. Such protracted conflict situations, where the UN's impartiality can be a problem in and of itself, "cannot be resolved by traditional methods, as the parties may not seek resolution." ${ }^{1}$

Tkach and Phillips consistently prove that the gaps in quantity and quality caused by the UN's organizational rigidity, financial flexibility, and procurement opaqueness are the core problems of PMSCs' greater engagement in UN peacekeeping missions. Thus, addressing these issues would reduce reliance on PMSCs. Their arguments seem to be correct from a procedural point of view. From a pragmatic point of view, PMSCS present a favorable solution, firstly, for the main fund donors and peacekeepers. They have been suffering from a kind of "peacekeeping fatigue" over the last 20 years. In this sense, the unclear fate of peacekeepers in high-risk regions, the unpredictable length and complexity of missions and the unwillingness of some parties to conflicts to negotiate peace, on the one hand, and the eagerness of the private security industry to embark on the job and the possibility of outsourcing at least a number of supportive tasks to PMSCs on the other, sideline future threats that PMSCs open to the violation of human rights.

The world order is becoming increasingly complex, as are conflicts and peacekeeping operations. New actors are emerging, seeking a place in the new reality and in international law. Old and well-known institutions increasingly face new circumstances they cannot ignore. While scholars and society debate the advantages and disadvantages of the use of PMSCs in conflict resolution operations and peacekeeping missions, the UN faces the task of keeping its numerous missions functioning across the world on a daily basis. The changing world requires flexibility and new approaches from both new and old actors to keep up with the pace of the fast-changing conditions. While PMSCs demonstrate greater flexibility and the ability to adapt to almost any environment, the UN could re-articulate its approach towards greater transparency in peacekeeping operations when contracting PMSCs. The absence of clear steps on the part of the UN opens the floor to new institutional organizations that can either pose an alternative to the existing bodies or even substitute recognized institutions by self-regulation mechanisms. ${ }^{2}$ The International Code of Conduct for Private Security Service Providers adopted in late 2010 is an example of this trend. ${ }^{3}$

To conclude, there are numerous shortcomings in the use of PMSCS in UN peacekeeping operations, yet it remains clear that the UN cannot do without them and perhaps does not want to. By now, the UN is a unique international forum that legitimizes or delegitimizes processes from the point of view of international law. The fact that the UN does not have any competition when it comes to peacekeeping operations, promoting human rights and maintaining peace and security means that it does not have to carry

3 "International Code of Conduct for Private Security Service Providers," ICoC, accessed December 16, 2020, https://icoca.ch/thecode/. 
out more thorough procedural reforms, introduce more transparent mechanisms and accounting procedures and be more open when it comes to security matters. Together with that, the proven capacity of PMSCs to engage in peacekeeping operations does not have to put UN peacekeeping standards at risk through their lack of accountability and legitimacy. It is clear that the PMSCs industry and the UN need to work together, not only on how to provide peace and security, but also towards becoming more transparent, establishing a clear vetting process and improving accountability mechanisms.

\section{СПИСОК ЛИТЕРАТУРЫ / REFERENCES}

Badell-Sánchez, Diego. "The Age of Outsourcing: UN Peacekeeping Operations.' In Peacekeeping: Global Perspectives, Challenges and Impacts, edited by Pablo Antonio Fernández Sánchez, 125-38. New York: Nova Science Publishers, 2018.

Bernales B., Enrique. Use of Mercenaries as a Means of Violating Human Rights and Impeding the Exercise of the Right of Peoples to Self-determination. UN doc. E/ CN.4/2004/15, December 24, 2003.

Bianchetti, Orlando. The Role of Private Military Security Companies in the New Generation of UN Peacekeeping Missions. Université de Lausanne / Universität Zürich, 2016.

Brooks, Doug. "Write a Cheque, End a War Using Private Military Companies to End African Conflicts." Conflict Trends, no. 6 (June 2000): 33-35. https://www. accord.org.za/publication/conflict-trends-2000-1/.

Cameron, Lindsey. The Privatization of Peacekeeping: Exploring Limits and Responsibility under International Law. Cambridge: Cambridge University Press, 2017.

Coady, Cecil A. John. "Mercenary Morality." In International Law and Armed Conflict, edited by Anthony Bradney, 55-71. Stuttgart: Franz Steiner Verlag, 1992. Cockayne, James, Mears Emily Speers, Cherneva Iveta, Gurin Alison, Oviedo Sheila, and Yaeger Dylan. Beyond Market Forces: Regulating the Global Security Industry. New York: International Peace Institute, 2009.

Cook, Tanya. "Dogs of War or Tomorrow's Peacekeepers?: The Role of Mercenaries in the Future Management of Conflict." The Culture Mandala 5, no. 1 (2002). http://www.international-relations.com/ wbcm5-1/wbmercenaries.htm.

Ettinger, Aaron. "The Mercenary Moniker: Condemnations, Contradictions and the Politics of Definition." Security Dialogue 45, no. 2. (April 2014): 174-91. https://doi.org/10.1177/0967010614521266.

Fallah, Katherine. "Corporate Actors: the Legal Status of Mercenaries in Armed Conflict." International Review of the Red Cross 88, no. 863 (2006): 599-611.

Findlay, Trevor. The New Peacekeepers and the New Peacekeeping. Working Paper no. 1996/2. Australian National University, Canberra ACT Australia, May 1996. https://openresearch-repository.anu.edu.au/ bitstream/1885/41679/4/96-2.pdf.

Fitzsimons, Lauren G. Should Private Military Companies be used in UN Peace Operations? E-International Relations, 2015. https://www.e-ir. info/2015/11/17/should-private-military-companies-beused-in-un-peace-operations/\#_ftn62.

George, Eric. "The market for peace." In From Market for Force to Market for Peace. Private Military and Security Companies in Peacekeeping Operations, edited by S. Gumedze, 17-39. Pretoria: Institute for Security Studies, 2011

Gomez del Prado, José Luis. "A U.N. Convention to Regulate PMSCs?" Criminal Justice Ethics 31, no. 3 (December 2012): 262-86. https://doi.org/10.1080/0731 129X.2012.743337.

Gumedze, Sabelo. "From Market for Force to Market for Peace: Private Military and Security Companies in Peacekeeping Operations." Pretoria, Institute for Security Studies, 2011.
Gumedze, Sabelo. "Pouring Old Wine Into New Bottles? The Debate Around Mercenaries and Private Military and Security Companies." In Elimination of Mercenarism in Africa: A Need for a New Continental Approach, edited by S. Gumedze, 21-44. Pretoria: Institute for Security Studies, 2008.

Hagedorn, Ann. The Invisible Soldiers: How America Outsourced our Security. New York: Simon \& Schuster, 2015. Krahmann, Elke. "From 'Mercenaries' to 'Private Security Contractors': The (Re)Construction of Armed Security Providers in International Legal Discourses." Millennium - Journal of International Studies 40, no. 2 (2012): 343-63. https://doi. org/10.1177/0305829811426673.

Kwaja, Chris M.A. "Private Military/Security Companies and Peacebuilding in West Africa." In From Market for Force to Market for Peace. Private Military and Security Companies in Peacekeeping Operations, edited by Sabelo Gumedze, 75-90. Pretoria: Institute for Security Studies, 2011

Lilly, Damian. The Privatization of Security and Peacebuilding: a Framework for Action. International Alert 2000.

Lumina, Cephas. "Counting the Cost: the Impact of Corporate Warfare on the Human Rights of Women and Children in Africa." In Elimination of Mercenarism in Africa: A Need for a New Continental Approach, edited by Sabelo Gumedze, 101-120. Pretoria: Institute for Security Studies, 2008.

Mbadlanyana, Thembani. "Moralpolitik and Realpolitik Seeking Common Ground on the Use of Private Military and Security Companies." In From Market for Force to Market for Peace. Private Military and Security Companies in Peacekeeping Operations, edited by Sabelo Gumedze, 39-74. Pretoria: Institute for Security Studies, 2011.

Mitchell, Sommer. Becoming Legitimate: How PMSCS are Seeking Legitimacy in the International System. University of South Florida, 2018.

Olaniyan, Azeez. "Unorthodox Peacekeepers and Responses in Africa." In From Market for Force to Market for Peace. Private Military and Security Companies in Peacekeeping Operations, edited by Sabelo Gumedze, 5-15. Pretoria: Institute for Security Studies, 2011.

Østensen, Åse Gilje. "In the Business of Peace: The Political Influence of Private Military and Security Companies on UN Peacekeeping." International Peacekeeping 20, no. 1 (2013): 33-47. http://dx.doi.org/ 10.1080/13533312.2012.761872.

Percy, Sarah V. "Mercenaries: Strong Norm, Weak Law." International Organization 61, no. 2 (2007a): 36797. DOI: https://doi.org/10.1017/S0020818307070130.

Percy, Sarah V. Mercenaries: The History of a Norm in International Relations. Oxford: Oxford University Press, 2007b.

Pingeot, Lou. Dangerous Partnership Private Military \& Security Companies and the UN. New York: Global Policy Forum and Rosa Luxemburg Foundation, 2012. Rosemann, Nils. Code of Conduct: Tool for SelfRegulation for Private Military and Security Companies. Occasional Paper No. 15. Geneva Centre for the Democratic Control of Armed Forces (DCAF), 2008. 
Schwartz, Moshe. The Department of Defense's Use of Private Security Contractors in Afghanistan and Iraq: Background, Analysis, and Options for Congress. Report for Congress. Congressional Research Service, May

13, 2011. http://www.fas.org/sgp/crs/natsec/R40835.pdf.

Shearer, David. "Outsourcing War. Why Mercenaries are a Fact of Warfare." Foreign Policy, September 15, 1998. https://foreignpolicy.com/1998/09/15/ outsourcing-war/.

Singer, Peter W. Corporate Warriors: The Rise of the Privatized Military Industry. New York: Cornell University Press, 2003.

Spearin, Christopher. "UN Peacekeeping and the International Private Military and Security Industry." International Peacekeeping 18, no. 2 (2011): 196-209. https://doi.org/10.1080/13533312.2010.546099.

Spicer, Tim. An Unorthodox Soldier: Peace and War and the Sandline Affair. Edinburgh: Mainstream Publishing Company (Edinburgh) Ltd., 1999.

Tkach, Benjamin, and Joe Phillips. “UN Organizational and Financial Incentives to Employ Private Military and Security Companies in Peacekeeping Operations." International Peacekeeping 27, no. 1 (2020): 102-23. https:// doi.org/10.1080/13533312.2019.1698296.

Кутейников, А. «Семья ООН»: Старые и новые члены // Международные процессы. - 2014. - Т. 12. № 4. - C. 66-77. [Kuteinikov, A. "'UN Family': Old and
New Members." [«Sem'ya OON»: Starye i novye chleny] International Trends 12, no. 4 (2014): 66-77] [In Russian]. Метелева, Е.Р. Разработка теоретико-методологических положений сетевого управления // Известия ИГЭА. - 2008. - № 3 (59). - С. 69-72. [Meteleva, E.R. "The Development of Theoretical and Methodological Approaches to Network Governance" [Razrabotka teoretiko-metodologicheskikh polozhenii setevogo upravleniya] Izvestiya IGEA, no. 3 (59) (2008): 69-72] [In Russian].

Никитин, А.И. Миротворчество ООН: обновление принципов, реформирование практики // Мировая экономика и международные отношения. - 2016. - Т. 60. № 3. - C. 16-26. [Nikitin, A.I. “United Nations Peacekeeping Operations: Reconsidering the Principles, Reforming the Practice." [Mirotvorchestvo OON: obnovlenie printsipov, reformirovanie praktiki] World Economy and International Relations 60, no. 3 (2016): 16-26] [In Russian].

Энтин, М.Л., Энтина, Е.Г. Обратно в юридическое средневековье? // Журнал зарубежного законодательства и сравнительного правоведения. - 2018. - № 2 (69). - C. 35-43. [Entin, M.L., and Ekaterina G. Entina. "Back to the Middle Age Law?" [Obratno v yuridicheskoe srednevekov'e?] Journal of Foreign Legis/ation and Comparative Law, no. 2 (69) (2018): 35-43. DOI: 10.12737/art.2018.2.5.] [In Russian].

\section{Author}

Maria A. Nebolsina,

$\mathrm{PhD}$ in Political Science, Researcher for the Center of Euro-Atlantic Security of the International Studies Institute, MGIMO University, 76 Vernadsky Avenue, Moscow, 119454.

e-mail: nebolsinama@gmail.com

\section{Additional information}

Received: July 16, 2020. Accepted: December 16, 2020.

\section{Funding}

The article was supported by a grant from the International Studies Institute at MGIMO University, Project No. 1921-01-07): "New Forms of Strategic Competition of the Great Political Powers in the $21^{\text {st }}$ Century" as part of the "Analysis and Forecasting the Evolution of International Relations in the Context of a Changing Technology" project.

\section{Disclosure statement}

No potential conflict of interest was reported by the author.

\section{For citation}

Nebolsina, Maria A. "Private Military and Security Companies in UN Peacekeeping Operations: Problems and Perspectives." Journal of International Analytics 11, no 3 (2020): 61-77. https: //doi/org/10.46272/2587-8476-2020-11-3-61-77 


\title{
Частные военные и охранные компании в миротворческих операциях 00Н: проблемы и перспективы
}

\begin{abstract}
АННОТАЦИЯ
В то время как некоторые государства-члены ООН воздерживаются от предоставления миротворцев по соображениям безопасности, $\mathrm{OOH}$ часто обращается за поддержкой к частному рынку безопасности. В свою очередь, частные военные и охранные компании (ЧВОК) берут на себя рискованные миссии и заполняют пробелы в снабжении. Общепринятой практикой является критика ЧВОК за то, что они не имеют четкого международно-правового статуса, действуют в "серой" зоне права и не несут ответственности за свои действия. Кроме того, ООН часто приравнивает ЧВОК к наемникам прошлого и призывает к строгому

регулированию и надзору за их деятельностью. Эта практика осталась неизменной

со времени реформ 1992 г., и ООН ничего не сделала для сокращения участия ЧВОК в миротворческих миссиях. Напротив, под давлением лобби частной охранной индустрии она фактически увеличила расходы на пользование услугами ЧВОК на беспрецедентные суммы.

Положение $\mathrm{OOH}$ как уникальной универсальной межправительственной организации освобождает ее от значительной прозрачности, подотчетности и реформ. В то время как частная охранная индустрия включает в себя различные ЧВОК, которые конкурируют

за контракты в зонах конфликтов и постконфликтных районах, у ООН нет никаких конкурентов в миротворческих процедурах. ООН критикует ЧВОК за их нарушения прав человека и пренебрежение международным правом, но продолжает нанимать их для своих миротворческих миссий. В данной статье рассматривается проблема вовлечения ЧВОК в миротворческие операции ООН. Она направлена на то, чтобы ответить на следующие основные вопросы: как ЧВОК, являясь партнерами ООН в миротворческом процессе, способствуют защите прав человека, что является одним из основных декларируемых принципов организации? Могут ли ЧВОК стать признанным инструментом в рамках системы $\mathrm{OOH?} \mathrm{Улучшатся} \mathrm{ли} \mathrm{миротворческие} \mathrm{усилия} \mathrm{ООН} \mathrm{в} \mathrm{результате} \mathrm{найма} \mathrm{ЧВОК?}$
\end{abstract}

\section{КЛЮЧЕВЫЕ СЛОВА}

ЧВОК, ООН, миротворческие операции, эффективность и результативность миссий, аутсорсинг и приватизация безопасности, наемничество, подотчетность чВОК

\section{Сведения об авторе}

Мария Александровна Небольсина, кандидат политических наук, научный сотрудник Центра евро-атлантической безопасности Института международных исследований МгИмо,

119454, Москва, Проспект Вернадского, 76.

e-mail: nebolsinama@gmail.com 


\section{Дополнительная информация}

Поступила в редакцию: 16 июля 2020. Принята к публикации: 16 декабря 2020.

\section{Сведения о финансировании}

Статья выполнена при поддержке гранта Института международных исследований МгИМО (проект № 1921-01-07): «Новые формы стратегической конкуренции великих политических держав в XXI веке» в рамках проекта «Анализ и прогнозирование эволюции международных отношений в контексте меняющихся технологий».

\section{Конфликт интересов}

Автор заявляет об отсутствии потенциального конфликта интересов.

\section{Цитирование}

Небольсина, М.А. Частные военные и охранные компании в миротворческих операциях ООН: проблемы и перспективы // Международная аналитика. - 2020. - Том 11 (3). - С. 61-77. https://doi.org/10.46272/2587-8476-2020-11-3-61-77 